УдК 339.9:330.341.1

\title{
ІННОВАЦІЙНІ ФОРМИ МІЖНАРОДНОГО БІЗНЕСУ В УМОВАХ ГЛОБАЛІЗАЦІї
}

\section{INNOVATIVE FORMS OF INTERNATIONAL BUSINESS IN THE CONDITIONS OF GLOBALIZATION}

\author{
Шталь Тетяна Валеріївна \\ доктор економічних наук, профресор, \\ Харківський національний економічний університет імені Семена Кузнеця \\ ORCID: https://orcid.org/0000-0003-1256-9854 \\ Дмитренко Дар'я Олександрівна \\ магістр, \\ Харківський національний економічний університет імені Семена Кузнеця \\ ORCID: https://orcid.org/0000-0003-3208-2453
}

\author{
Shtal Tatyana, Dmytrenko Daria \\ Simon Kuznets Kharkiv National University of Economics
}

В сучасних умовах глобалізаційного розвитку Україна стає активним суб'єктом на глобальному ринку товарів і послуг. В статті зосередженні дослідження теоретичних елементів розвитку інноваційних фрорм міжнародного бізнесу. Відображено функції та сутність міжнародного бізнесу. Сучасний міжнародний бізнес розкриває високий рівень організації, складні різноманітні та гнучкі системи управління, які ефрективно здійснюють господарську діяльність на глобальному рівні. Визначено сутність поняття «інноваційні фрорми міжнародного бізнесу», являють собою традиційні фрорми, які транссрормуються та набувають нових якостей за рахунок впливу глобалізації, процесів інтернаціоналізації. Представлено загальні тенденції розвитку бізнесу в залежності від змін, що несуть в собі пандемія, а також акцентується увага на особливостях впливу знань, інновацій та інсрормацій на даний сектор бізнесу.

Ключові слова: тенденції, міжнародний бізнес, інновації, інноваційний розвиток, стратегії, фрорми міжнародного бізнесу, пандемія COVID-19.

В современных условиях глобализационного развития Украина становится активным субъектом на глобальном рынке товаров и услуг. В статье сосредоточены исследования теоретических элементов развития инновационных фрорм международного бизнеса. Отражены функции и сущность международного бизнеса. Современный международный бизнес раскрывает высокий уровень организации, сложные разнообразные и гибкие системы управления, эфрфективно осуществляющие хозяйственную деятельность на глобальном уровне. Определена сущность понятия «инновационные фрормы международного бизнеса», представляют собой традиционные фрормы, которые трансфрормируются и приобретают новые качества за счет влияния глобализации, процессов интернационализации. Преставлены общие тенденции развития бизнеса в зависимости от изменений, несущих пандемию, а также акцентируется внимание на особенностях влияния знаний, инноваций и инорормаций на данный сектор бизнеса.

Ключевые слова: тенденции, международный бизнес, инновации, инновационное развитие, стратегии, фрормы международного бизнеса, пандемия COVID-19.

In the current conditions of globalization, Ukraine is becoming an active player in the global market of goods and services. The article focuses on the study of theoretical elements of the development of innovative forms of international business. A variety of theoretical approaches to defining the essence of the concept of "international business", which allowed to clarify the concept of international business, which is considered as the interaction of two or more enterprises of different forms of ownership or their units located in different countries, each with specific economic, legal, socio-cultural, political, ideological, natural-climatic and geographical environment, which leads to more efficient use of resources and such interaction which is based on entrepreneurial activity for profit. Modern international business reveals a high level of organization, complex, diverse and flexible management systems that effectively carry out economic activities at the global level. 2020 marked the beginning of the global economic crisis due to the COVID-19 pandemic. This crisis is currently the worst in 10 years. As a result, most economies around the world are in dire straits. All the world's economies experienced a record drop in GDP in the second quarter of 2020, which was more significant than it was during the global economic crisis of 2008. The main forms of international business are determined and the prospects of their development 
in modern conditions are characterized. The essence of the concept of "innovative forms of international business" is defined, they are traditional forms that are transformed and acquire new qualities due to the influence of globalization, internationalization processes. The general tendencies of business development depending on the changes brought by a pandemic are presented, and also attention is paid to features of influence of knowledge, innovations and information on the given sector of business. Proposals for ways of adaptation and changes in the industry for further existence were presented, as well as possible solutions that will help international business to sustain and develop in the future.

Keywords: tendencies, international business, innovations, innovative development, strategies, forms of international business, COVID-19 pandemic.

Постановка проблеми. Прогноз розвитку міжнародного ринку на теперішній час, цікавить багатьох, як великих інвесторів, так i пересічних громадян. Насамперед оскільки в сорері сучасного міжнародного ринку відбуваються найсуперечливіші та складні суспільні процеси. Сучасний міжнародний ринок, порівняно з національним, більш складніше явище, на яке впливає безліч фракторів та діють власні закони, оскільки кожна країна має свої особливості. Залучення та удосконалення інноваційної сорери в міжнародному бізнесі, в порівнянні 3 традиційними стратегіями, дає додаткові можливості, насамперед для удосконалення та підтримки міжнародного ринку.

Формулювання цілей статті (постановка завдання). Мета статті полягає у дослідженні особливостей та тенденцій розвитку міжнародного бізнесу в контексті глобальної економіки та обґрунтуванні теоретичних основ розвитку інноваційних форм міжнародного бізнесу.

Аналіз останніх досліджень і публікацій. Загалом темі основним тенденціям міжнародного бізнесу приділено велику увагу як в Україні, так і за кордоном. Процес розвитку міжнародного бізнесу в своїх працях вивчали такі зарубіжні вчені: Р. Гріфффін, М. Пастей, О. Лааш, Р. Коневей. Серед вітчизняних вчених можна додати Т.В. Шталь, Н.В. Проскурніна, К.П. Болдовська, В.І. Кокоріна, Н.О. Власова, Н.Л. Савицька, В.А. Гросул та інші. Теоретикометодологічні основи дослідження економіки знань і практичних розробок в якісно нових умовах міжнародного бізнесу закладені в роботах П. Друкера, Г. Іцковіца, Б.-А. Лундвалла, Ф. Махлуп, Дж. Мокіра, Дж. Стігліца, Д. Форея та інших. Незважаючи на велику кількість досліджень та вивченість теми, на теперішній час, дана проблема залишається актуальною, оскільки середовище міжнародного бізнесу швидко змінюється, проявляючи нові тенденції.

Виклад основного матеріалу. Для того щоб зрозуміти основу фрорм розвитку міжнародної бізнес стратегії необхідно розглянути сутність та основу міжнародного бізнесу. Зарубіжні вчені Р. Гріфрфіном та М. Пастей вважають, що «міжнародний бізнес» розглядається, як здійснення ділових операцій партнерами 3 більш ніж однієї країни [1, с. 45]. Для таких вчених як, Р. Коневей та О. Лааш, думка сходиться на тому, що «міжнародний бізнес складається з усіх комерційних угод, у тому числі продаж, інвестицій і транспорту, з усього, що має місце між двома або більше країнами» [2].

На нашу думку, міжнародний бізнес «покликаний забезпечувати організацію трансфрерту капіталу у вигляді повного чи часткового володіння» [3].

У роботі К.П. Болдовська міжнародний бізнес представляється як «система, що охоплює сукупність контрагентів міжнародних економічних відносин і інтегруючу їх діяльність в одне ціле» [4, с. 13].

Так, В.І. Кокоріна зазначає, що «міжнародний бізнес, будучи потужним інструментом економічної інтеграції, а відтак і глобалізації, визначається такими характеристиками, як: доступність і загальність, ієрархічність розвитку, технологічна глобалізація, фрінансіаризація, взаємодія національного й інтернаціонального менталітету, знання і компетентність» [5].

Н.О. Власова вважає, що міжнародний бізнес значно залежить від міжнародної торгівлі, що дозволяє науково обґрунтовувати торговельну стратегію, яка відповідає індивідуальним (часом унікальним) умовам та цілям конкретної країни [6].

Досліджуючи наукові економічні праці можна дійти висновку, що міжнародний бізнес представляється системою взаємовідносин між двома або більше країнами, на взаємних вигодах.

Розглядаючи фрорми міжнародного бізнесу, можна сказати що вони стають все більш різноманітними. До основних фрорм міжнародного бізнесу відноситься: експорт та імпорт товарів і послуг, управління контрактами, ліцензування, міжнародні корпорації та спільні підприємства.

Необхідно підкреслити, те що експорт являє собою найпростішу фрорму міжнародного бізнесу та становить собою продаж товарів чи послуг в інші країни. В сучасних умовах розвитку зовнішньоторговельної операції становить понад 80\% обсягів міжнародного бізнес. Але, слід зазначити, що експорт є най- 
менш прибутковою фрормою міжнародного бізнесу хоча і менш ризикованою.

При докладному дослідженні форм міжнародного бізнесу має доцільно загострити увагу, що ліцензування означає прав інтелектуальної власності іншій країні за умовами отримання певних коштів. Під інтелектуальною власністю слід вважати технологію виробництва, торгові марки, «ноу-хау» та інше. Дана фрорма міжнародного бізнесу частіше поєднується з фрранчайзинговими угодами.

На нашу думку, спільні підприємства, як форма міжнародного бізнесу широко використовується незалежними країнами для виходу на нові іноземні ринки. Найпоширенішими були двосторонні спільні підприємства, де іноземний учасник робив свій внесок в бізнес капіталом, новими технологіями та «ноу-хау», а місцевий засновник надає приміщення та інші матеріальні активи.

Дивлячись на міжнародні корпорації, як на фрорму міжнародного бізнесу, слід підкреслити що вони являють собою великі об'єднання промислових, торгових, транспортних або банківських фрірм та компаній, діяльність яких виходить далеко за межі країн базування та безпосередньо забезпечують їм сприятливі позиції у виробництві, збуті, закупівлі товарів і наданні послуг. Однак, слід зазначити що інновації, знання та інформаційні технології стають домінуючими чинниками зміни форм міжнародного бізнесу.

Стратегія інноваційного розвитку формується, насамперед, на підставі оцінки аналізу реальної та потенціальної інноваційної активності організації. На рис. 1 показано, що інноваційна активність відображає інтенсивність зусиль для повного залучення наявних ресурсів в інноваційну діяльність та досягнення достатнього рівня інноваційного розвитку.
Вивчення та визначення стану сучасного міжнародного бізнесу зумовлює більш глибоке розуміння процесу, що відбувається, а в зв'язку з цим, виникнення інноваційних фрорм міжнародного бізнесу на міжнародному ринку, так за період 2019-2020 рр. через введення карантинних обмежень міжнародний бізнес був змушений використовувати нові технології. Зараз багато міжнародних компаній стали працювати дистанційно, через що значно збільшився попит на програми такі як Zoom, Skype та інші. Спочатку це було дуже складно для всіх, але зараз більшість компаній схиляються до думки, що дистанційна робота є більш продуктивною за роботу в офрісі.

Також, пандемія COVID-19 посилила небезпеку в кіберпросторі, збільшилась кількість шахрайських веб-сторінок, які обдурюють громадянин збираючи пожертви або надають рекомендації щодо лікування короно вірусом. Враховуючи вище сказане, компаніям міжнародного бізнесу слід розробляти та удосконалювати програми захисту від кіберзлочинців.

Аналізуючи вплив пандемії на інноваційну діяльність міжнародного бізнесу України, слід зазначити що до пандемії науці та інноваціям в країні відводилась другорядна роль. Оскільки стан кластерного розвитку в 2019 році був слабо організований, що негативно впливало на формування середовища для розвитку малих інноваційних підприємств (стартапів) та підприємницьких ініціатив. Розглядаючи витрати країни на виконання наукових досліджень та розробок у 2019 році порівняно 3 2018 роком знизилось з 0,47\% ВВП до 0,43\% ВВП. На кінець 2020 року капітальні інвестиції у ссреру наукових досліджень та розробок скоротились у річному вимірі на $41 \%$, кластерний рух України залишається не контролюючим [8].

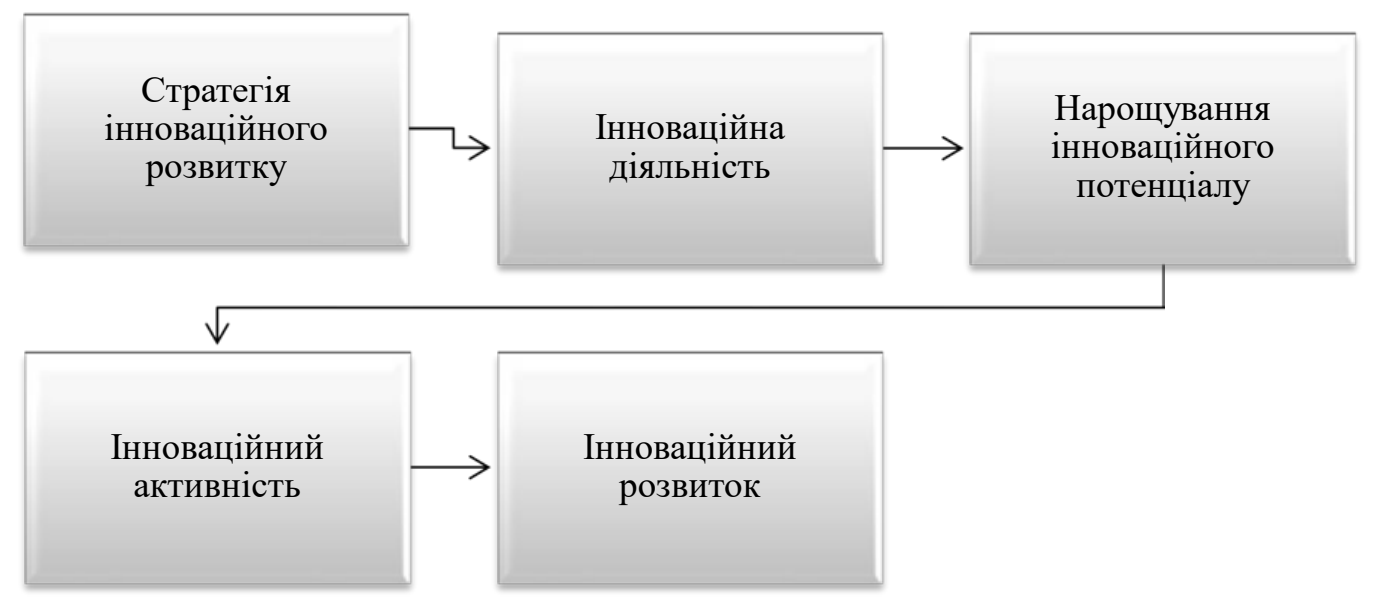

Рис. 1. Визначення категорії «інноваційна активність» 
Можна зробити висновки, що пандемія COVID-19 не сприяла зміцненню та удосконаленню акцентів економічної політики України у бік інновацій. Однак, для успішного виходу України з теперішньої кризи та для забезпечення сталого розвитку міжнародного бізнесу, Уряду України варто, на нашу думку, більше загострити увагу питанню фрінансування науки та створенню сприятливого та успішного розвитку нових стартапів і розвитку інновацій.

Висновки. Отже, сходячи 3 проведеного дослідження можна дійти висновку, що міжнародний бізнес представляється системою взаємовідносин між двома або більше країнами, на взаємних вигодах. Тема розвитку міжнародного бізнесу включає в себе велику кількість комплексних процесів, що повинні розглядатися та вивчатися не тільки вченими, але й бізнесменами. Оскільки отриманні знання міжнародного бізнесу допоможе в розробці та впровадженні достойної стратегії компанії та сприятиме ефрективного шляхів розвитку міжнародного бізнесу компанії. На теперішній час більш доцільно упроваджувати та удосконалювати інновації в міжнародний бізнес, особливо в період пандемії.

\section{СПИСОК ВИКОРИСТАНИХ ДЖЕРЕЛ:}

1. Грифффин Р., Пастей М. Международный бизнес. 4-е изд. / Пер. с англ. под ред. А. Г. Медведева. СПб. : Питер, 2006. 1088 с.

2. Laasch O. Glocal Sustainability, Responsibility and Ethic / O. Laasch, R.N. Conaway. 1st Edition. Cengage Learning, USA, Copyright. 2015. 576 p.

3. Шталь Т.В., Козуб В.О., Бондаренко Л.М. Формування інвестиційної стратегії вітчизняним підприємством у міжнародному бізнесі. Науковий вісник Ужгородського університету. 2017. № 1(49). С. 213-216.

4. Сучасні тенденції розвитку світової економіки : збірник матеріалів X Міжнародної науково-практичної конференції (18 травня 2018 р. м. Харків.). Харків : ХНАДУ, 2018. 308 с. URL: https://fmab.khadi.kharkov.ua/ uploads/media/Conf_18.05.2018_KhNAHU_.pdf (дата звернення: 15.10.2021).

5. Кокоріна В.І. Імперативи розвитку міжнародного бізнесу в умовах глобалізації. Держава та регіони. Серія : Економіка та підприємництво. 2010. № 3. С. 67-73.

6. Власова Н.О., Гросул В.А., Краснокутська Н.С., Круглова О.А., Чорна М.В., Филипенко О.М. Економіка торгівлі : навч. посібник. Харків. держ. ун-т харчування та торгівлі. Харків : Світ книг, 2015. 473 с.

7. Гринько П.Л. Управління інноваційним розвитком бізнесу в умовах цифрової економіки: теорія, методологія, практика: монограсрія / за ред. Іванченка І.С. Харків : Видавництво Іванченка І.С., 2020. 342 с.

8. Офріційний сайт Державної служби статистики України. URL: http://www.ukrstat.gov.ua/ (дата звернення: 29.10.2021).

\section{REFERENCES:}

1. Hryffyn R., Pastey M. (2006) Mezhdunarodnyy byznes [International Business]. SPb.: Pyter, 1088 p. (in Russian)

2. Laasch O., Conaway R.N. (2015) Glocal Sustainability, Responsibility and Ethic [Glocal Sustainability, Responsibility and Ethic]. 1st Edition. Cengage Learning, Copyright, 576 p. (in USA)

3. Shtal T.V., Kozub V.O., Bondarenko L.M. (2017) Formuvannya investytsiynoyi stratehiyi vitchyznyanym pidpryyemstvom u mizhnarodnomu biznesi [Formation of investment strategy by a domestic enterprise in international business]. Naukovyj visnyk Uzgorodskogo nacionalnogo universytetu, 1(49), 213-216. (in Ukrainian)

4. Boldovs'ka K.P., Andryeyeva D.V. (2018) Kharakterni rysy mizhnarodnoho biznesu [Characteristic features of international business]. Proceedings of the Suchasni tendentsiyi rozvytku svitovoyi ekonomiky: zbirnyk materialiv X Mizhnarodnoyi naukovo-praktychnoyi konferentsiyi. (Ukrainian, Kharkiv, May 18, 2018), Kharkiv: Suchasni tendentsiyi rozvytku svitovoyi ekonomiky, pp. 13. Available at: https://fmab.khadi.kharkov.ua/uploads/ media/Conf_18.05.2018_KhNAHU_.pdf (accessed 15 October 2021). (in Ukrainian)

5. Kokorina V.I. (2010) Imperatyvy rozvytku mizhnarodnoho biznesu v umovakh hlobalizatsiyi [Imperatives of international business development in the context of globalization]. Derzhava ta rehiony. Seriya: Ekonomika ta pidpryyemnytstvo, 3, 67-73. (in Ukrainian)

6. Vlasova N.O., Hrosul V.A., Krasnokut.s'ka N.S., Kruhlova O.A., Chorna M.V., Fylypenko O.M. (2015) Ekonomika torhivil [Economics of trade]. Kharkiv: Svit knyh. (in Ukrainian)

7. Hryn'ko P.L. (2020) Upravlinnya innovatsiynym rozvytkom biznesu v umovakh tsyfrovoyi ekonomiky: teoriya, metodolohiya, praktyka: monohrafiya [Management of innovative business development in the digital economy: theory, methodology, practice: monograph]. Kharkiv: Ivanchenko I.S. (in Ukrainian)

8. Oficijnyi sajt Derzavnoi sluzby statystyky Ukrainy [Official site of the State Statistics Service of Ukraine]. Available at: http://www.ukrstat.gov.ua/ (accessed 29 October 2021). (in Ukrainian) 